\title{
DNA-based analysis of shark products sold on the Indonesian market towards seafood labelling accuracy program
}

\author{
ASADATUN ABDULLAH ${ }^{1, \boldsymbol{v}}$, MALA NURILMALA ${ }^{1}$, EFIN MUTTAQIN $^{2}$, IRFAN YULIANTO ${ }^{2}$ \\ ${ }^{1}$ Department of Aquatic Product Technology, Faculty of Fisheries and Marine Science, Institut Pertanian Bogor. Jl. Agatis, Kampus IPB Dramaga, Bogor \\ 16680, West Java, Indonesia. Tel.: +62-251-8622915, Fax.: +62-251-8622916, •email: asadatun.abdullah@gmail.com \\ ${ }^{2}$ Wildlife Conservation Society-Indonesia Program. Jl. Malabar 1 No.11, Bogor 16128, Bogor, West Java, Indonesia
}

Manuscript received: 16 January 2020. Revision accepted: 10 March 2020.

\begin{abstract}
Abdullah A, Nurilmala M, Muttaqin E, Yulianto I. 2020. DNA-based analysis of shark products sold on the Indonesian market towards seafood labelling accuracy program. Biodiversitas 21: 1385-1390. Authentication of fishery products has relied mainly on DNA analysis of mitochondrial genes such as cytochrome c oxidase I (COI) DNA barcoding and cytochrome b (cyt b) gene fragments. The trend of sharks and rays food products trading in Indonesia significantly increased, due to their important role as protein source which may threaten the vulnerability status of some species. This study was aimed to determine the reliability of COI mini-DNA barcode and cyt $b$ fragment for identification of shark species of heavily processed fishery products. We found the mini-DNA barcode was an effective tool to identify the shark species traded in local markets with most of the sample identifies as Carcharhinus falciformis. Our results highlight the urgency of applying DNA-based method as a routine method to control the labelling of Indonesian fish products and to manage sustainable fisheries.
\end{abstract}

Keywords. Authentication, COI, Cyt b, mini DNA barcode, seafood, sharks

\section{INTRODUCTION}

Unmanaged shark fisheries in Indonesia have been long history, hence, there are efforts to achieve sustainable fisheries. Previously, it has been reported about fish landing monitoring and trade of critically endangered Indonesian sharks and rays (Sembiring et al. 2015; Yulianto et al. 2018). Sharks and rays belong to Elasmobranch group which known to exhibit low fecundity and late sexual maturation (Bornatowski et al. 2014; Almeron-Souza et al. 2018). This group of fish has gained worldwide attention concerning conservation and management due to their high vulnerability to extinction. The trend of globally trading of their meat reached $42 \%$ from 2000 to 2011 (FAO 2015; Almeron-Souza et al. 2018). In some regions, sharks remain important protein sources for human foods and some of their body parts have been ingredients for popular dishes (Steinke 2017; Muttaqin et al. 2019; Giovos et al. 2020). Due to high demand in shark trade, their population in nature has been declining with one in four Chondrichthyan species being threatened or near-extinct (Dulvy et al. 2014). The common product sold in the market (local or international) is shark fins, however, there is also an increasing trend of shark meat consumption particularly in Indonesia as the world largest shark fishery (Dent and Clarke 2015; Dulvy et al. 2017).

Processed fish products have added value and attractiveness for consumers, as well as longer shelf life. The common shark products traded in Indonesian market are headless, fillets, fillet-block or surimi-based products, smoked, salted, boiled fillets and broiled fillets. One of the many efforts to overcome mislabeling and illegal substitution is seafood label inspection and authentication. Identification can be done with a morphological characteristic approach, but processing such as heating, freezing, canning, salted and smoked can make identification process become difficult (Zhao et al. 2013). Morphological identification of the landed shark only possible whereas all morphological traits is complete. In the case of processed shark products molecular based identification tool is urgently required to verify the correct species assignation of endangered shark species (Sembiring et al. 2015; Kim et al. 2018; Pazartzi et al. 2019).

Seafood fraud, in particular mislabeling and species substitution, have been raising concerns for consumers. Consumers will suffer economic losses by obtaining cheaper fish or in the worst-case damage their health (Jacquet and Pauly 2008). The fraudulent activities in seafood market were caused by several factors such as fishery stock depletion in many countries, the absences of government policy in governing seafood labeling and unequal law enforcement of mislabeling conduct in many parts of the world (Armani et al. 2015; Shokralla et al. 2015; Xiong et al. 2018). Mislabeling has been detected in $82 \%$ of commercial fish fillets in Italy (Di Pinto et al. 2015), 24\% of seafood in South Brazil (Carvalho et al. 2015), 50\% of fish products in Germany (Kappel and Schroder 2016), 22\% of seafood in India (Nagalakshmi et al. 2016), and $28 \%$ in Brazil (Staffen et al. 2017). Currently, there is no official reference list of Indonesian seafood and fishery products trading names. The local names of many important commercial fish species vary between areas and thus lead to confusion for traders. In 
order to fulfill the demand for international seafood market quality standards as well as the urgent issue of sustainability, the fast and reliable method is needed.

Authentication of fishery products is important not only to comply with international market demand but also to provide useful information related sustainability of several fish species with vulnerable status. The study of Horreo et al. (2019) described mislabeling of fish products in restaurant was common and some species might be more vulnerable to fraud than the others. Particular fish species could be substituted with other species with lower economical value. Authentications of food products have been using various methods, in general, the protein-and DNA-based methods. Over the last decade, DNA barcoding systems for animals have been offered the opportunity to standardize species identification in seafood traceability (Barbuto et al. 2010; Abdullah and Rehbein 2017; Stern et al. 2017). DNA barcoding of animals is based on a standardized 655-bp region of the $\mathrm{mt}$ cytochrome c oxidase subunit I gene (COI) with the purpose of identifying variations among species. The COI gene fragment was initially proposed as a universal animal bio-identification system (Hebert et al. 2003). In addition to COI gene fragment, many scientists have been applied the cytochrome b (cyt b) gene fragment. Cyt b gene fragment is one of the most extensively sequenced genes in vertebrates and successfully applied for fish species identification (Horreo et al. 2013; Huang et al. 2014).

However, various cooking methods might reduce the quality and success of DNA sequencing, thus alternative method is needed (Shokralla et al. 2015). Identification with full-length DNA has a success rate of $20.5 \%$, whereas DNA mini-barcodes is $93.2 \%$ of 44 processed fish products (Shokralla et al. 2015). Full-length DNA barcode (FDB) fragments with 520-655 bp fragments successfully amplified 50\% (processed) and 81\% (ethanol-preservative), while the ability of Mini-length DNA barcode (MDB) amplification with fragments of $60-139$ bp is higher, namely $100 \%$ (processed) and 94\% (ethanol-preservative) (Armani et al. 2015). DNA mini-barcodes (295 bp) succeeded in authenticating 33 processed fish products including fish ball, fish finger, fillet, and canned fish (Sultana et al. 2018), and mini barcodes (320 bp) in $43.2 \%$ of fish processed products from 112 samples that were not successfully amplified with full length (Guenther et al. 2017). Therefore, this study was aimed to authenticate heavily processed sharks products using COI DNA minibarcode and cytochrome $b$ gene markers.

\section{MATERIALS AND METHODS}

\section{Sample collection}

Various fresh and processed shark products (36 samples), were collected from commercial sources (fishlanding industries, fish processing industries, commercial food markets and restaurants of Indonesian origin particularly in Aceh and West Nusa Tenggara, Indonesia (Figure 1).

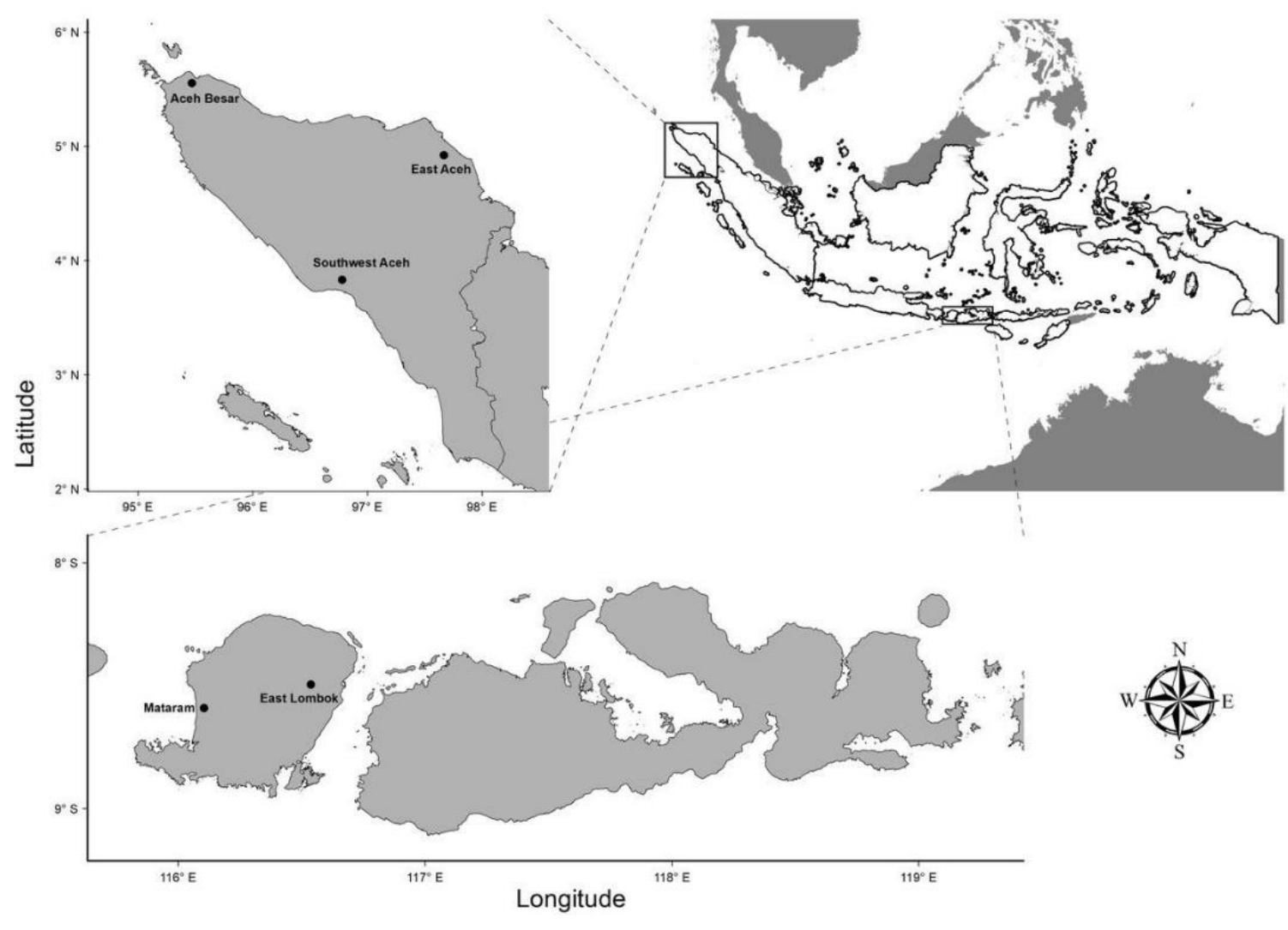

Figure 1. Sampling sites of processed shark's products in Aceh and West Nusa Tenggara provinces, Indonesia 
All of processed shark products in this study were in the form of cooked with heavy seasoning, smoked, salted or mixed products which focused in certain areas of sampling (Aceh and West Nusa Tenggara). Specific areas of sampling (East Aceh, Southwest Aceh and Mataram region) were mainly due to the fact that those regions are the major shark consumers within Indonesian society. Collected tissue samples were transported to the Bogor Agricultural University's laboratory and stored at $-20^{\circ} \mathrm{C}$ before used.

\section{Molecular analysis laboratory works}

All genomic DNA from sharks and ray's products were extracted using Qiagen DNeasymericon Food Kit (QIAGEN, Hilden, Germany). Due to possibility of excessive rate of DNA fragmentation in highly processed food items, shorter DNA barcode fragment of COI gene region was applied and validated. The isolated DNA concentrations of shark products were measured by NanoDrop 2000 Spectrophotometer (Thermo Fisher Scientific, USA). Mini-DNA barcoding amplification protocol was according to previous research from Shokralla et al. (2015), the SHE-F and SHE-R primer pair were used to amplify the heavily processed shark products based on their previous positive results. All PCR analyses in this study were prepared with the PCR master mix kit Qiagen HotStarTaq Plus DNA Polymerase (QIAGEN, Hilden, Germany) and the protocol was: $25 \mu \mathrm{L}$ reaction volume containing: $1-2 \mathrm{ng}$ DNA $\mu \mathrm{L}^{-1}, 1.0 \mu \mathrm{M}$ of primers. The primer concentration was approximately $0.5 \mu \mathrm{M}$ (= $\mathrm{pmol} / \mu \mathrm{L})$. PCR condition of mini-DNA barcode were as follows: initial denaturation $5 \mathrm{~min}$ at $95^{\circ} \mathrm{C}$, followed by denaturation 35 cycles of $40 \mathrm{~s}$ at $94^{\circ} \mathrm{C}$, annealing $1 \mathrm{~min}$ at $46^{\circ} \mathrm{C}$ and extension $30 \mathrm{~s}$ at $72^{\circ} \mathrm{C}$ with final extension $7 \mathrm{~min}$ at $72^{\circ} \mathrm{C}$. The 464 -bp cyt $\mathrm{b}$ gene fragment applied in order to increase the success rate of species identification process (Wolf et al. 2000). The cycler protocol for the cyt b gene was an initial step of $5 \mathrm{~min}$ at $95^{\circ} \mathrm{C}$, followed by 35 cycles of $1 \mathrm{~min}$ at $94^{\circ} \mathrm{C}, 1 \mathrm{~min}$ at $50^{\circ} \mathrm{C}$ and $1 \mathrm{~min}$ at $72^{\circ} \mathrm{C}$, followed by a final extension of $10 \mathrm{~min}$ at $72^{\circ} \mathrm{C}$. The cyt b primer was terminated at the $5^{\prime}$-end with additional primers, M13F: 5'-CCA GGG TTT TCC CAG TCA CG-3' and M13R: 5'-CGG ATA ACA ATT TCA CAC AGG-3' used for sequencing of amplicons (Messing 1983).

In addition, all products were stored in $-20^{\circ} \mathrm{C}$ before processed further in sequencing step. Following PCR analysis, $5 \mu \mathrm{L}$ of the PCR products will be visualized on a $1 \%$ agarose gel and the expected amplicons were compared with the standard marker 100-bp DNA ladder (Roth, Carl Roth $\mathrm{GmbH}$, Karlsuhe, Germany) before the bi-directional sequencing process performed using the Sanger method (LGC Group, Berlin, Germany).

\section{Genetic data analysis}

The nucleotide sequences of mini-DNA barcodes were first analyzed using BOLD (Identification System or IDs) (http://boldsystem.org/index.php/IDS_OpenIdEngine) and the sequences were cross-examined using the Basic Local Alignment Search Tool (BLASTn) in GenBank
(http://blast.ncbi.nlm.nih.gov/BLAST.cgi). We determined the threshold for species delimitation of maximum $2 \%$. Manual inspection of chromatograms was done in order to ensure the reliability of generated data. Each nucleotide sequence was checked from insertion and deletion or stop codon, removed from primer sequences and aligned using ClustalW and Mega 6.0 integrated software (Tamura et al. 2013).

\section{RESULTS AND DISCUSSION}

\section{Molecular analysis and species identification}

Total genomic DNA was successfully isolated from all samples, with the concentration ranging from 24.15-37.80 $(\mathrm{ng} / \mu \mathrm{L})$. Some of the isolated DNA in this study was found partially fragmented when visualized by DNA electrophoresis analysis (data not shown). The DNA fragmentation of shark and rays product potentially caused by the complex process of food processing, in our case: mechanical stress, high temperature, as well as addition of high amount of salt and hot smoke. Results from previous researches demonstrated high temperature, $\mathrm{pH}$ variation, fermentations and seasoning addition into food materials could degrade the isolated DNA by affecting their primary structure (Lindahl 1993; Gryson 2010; Xiong et al. 2018).

All genomic DNA in this study failed to be amplified using full-length DNA barcodes (data not shown). However, mini-DNA barcode amplification demonstrated all samples were successfully amplified and sequenced. Researches using COI or $c y t b$ mitochondrial DNA barcoding have been increased in decade and was successful to identify seafood products as well as investigate the fish mislabeling problems. Moreover, to overcome problems in authentication of heavily processed products, mini DNA barcode of shorter fragments $(\sim 100$ $400 \mathrm{bp}$ ) developed in previous studies as an alternative to full-lengths DNA marker. This method has been proven effective for DNA sequences determination from degraded DNA with more than $90 \%$ species resolutions (Hajibabaei et al. 2006; Shokralla 2015; Xiong et al. 2018).

The results indicate all of the sharks and rays PCR products gave 226 bp (COI mini-DNA barcode) and $464 \mathrm{bp}$ (cyt b) readable sequences with no insertion, deletion or stop codon detected in the sequences. Both markers of COI mini DNA barcode and cyt b gave $100 \%$ success rate until species designation process. There is no ambiguity in the resolving power for both markers when analyzed using two databases NCBI and BOLD. Species identity hits retrieved for both databases were ranged between 98-99\% (Table 1). Mini-DNA barcodes were previously described as a promising tool for fish and seafood authentication particularly the cooked products. In comparison to fulllength DNA barcodes, previous studies found mini-DNA barcode demonstrated high potential over full-length DNA barcodes (Armani et al. 2015; Shokralla et al. 2015; Pollack et al. 2018) for processed food products. 
Table 1. Sharks and ray's samples information and the identification results

\begin{tabular}{|c|c|c|c|c|c|c|c|c|c|c|}
\hline \multirow{2}{*}{ 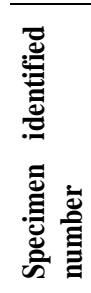 } & \multirow[b]{2}{*}{ 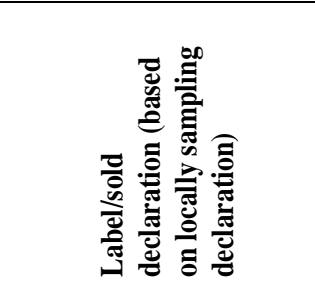 } & \multirow[b]{2}{*}{ 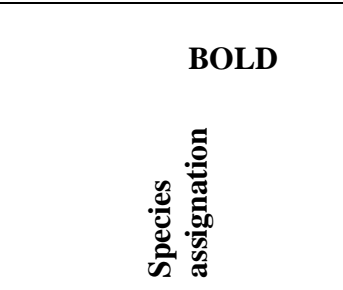 } & \multirow{2}{*}{\multicolumn{2}{|c|}{$\begin{array}{l}\text { COI Mini-barcode } \\
\text { NCBI }\end{array}$}} & \multirow[b]{2}{*}{ 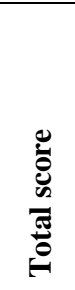 } & \multirow[b]{2}{*}{ 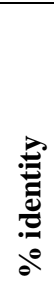 } & \multicolumn{2}{|l|}{ Cytb } & \multirow[b]{2}{*}{ 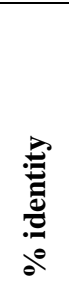 } & \multirow[b]{2}{*}{ 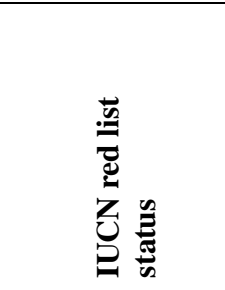 } \\
\hline & & & & & & & 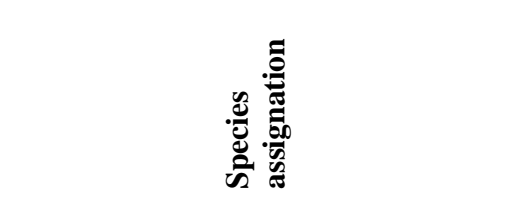 & 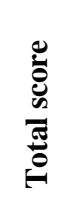 & & \\
\hline$\overline{\text { PS1 }}$ & Processed shark meat & Carcharhinus sorrah & 8.81 & archarhinus sorrah KF612341.1 & 457 & 99 & Carcharhinus sorrah KF612341.1 & 802 & 99 & Near Threaten \\
\hline PS2 & Processed shark meat & Carcharhinus falciformis & 98.39 & Carcharhinus falciformis MH911159.1 & 446 & 99 & Carcharhinus falciformis KF801102.1 & 804 & 99 & Vulnerable \\
\hline PS3 & Processed shark meat & Carcharhinus falciformis & 98.39 & Carcharhinus falciformis MH911159.1 & 446 & 99 & Carcharhinus falciformis KF801102.1 & 804 & 99 & Vulnerable \\
\hline CM1 & Cooked meat & Alopias pelagicus & 97.62 & Alopias pelagicus KF020876.1 & 436 & 98 & Alopias pelagicus KF020876.1 & 797 & 99 & Vulnerable \\
\hline $\mathrm{CM} 2$ & Cooked meat & Alopias pelagicus & 97.62 & Alopias pelagicus KF020876.1 & 436 & 98 & Alopias pelagicus $\mathrm{KF} 020876.1$ & 797 & 99 & Vulnerable \\
\hline DF1 & Salted shark meat & Carcharhinus falciformis & 98.39 & Carcharhinus falciformis MH911159.1 & 446 & 99 & Carcharhinus falciformis KF801102.1 & 809 & 99 & Vulnerable \\
\hline DF2 & Salted shark meat & Carcharhinus falciformis & 98.39 & Carcharhinus falciformis MH911159.1 & 446 & 99 & Carcharhinus falciformis KF801102.1 & 806 & 99 & Vulnerable \\
\hline DF3 & Salted shark meat & Carcharhinus falciformis & 98.39 & Carcharhinus falciformis MH911159.1 & 446 & 99 & Carcharhinus falciformis KF801102.1 & 804 & 99 & Vulnerable \\
\hline SS1 & Shark's Skin & Rhynchobatus australiae & 98.41 & Rhynchobatus australiae KU746824.1 & 448 & 98 & Rhynchobatus australiae KU746824.1 & 800 & 99 & Vulnerable \\
\hline SS2 & Shark's Skin & Rhynchobatus australiae & 98.41 & Rhynchobatus australiae KU746824.1 & 448 & 98 & Rhynchobatus australiae KU746824.1 & 806 & 99 & Vulnerable \\
\hline SF1 & Shark's fin & Galeocerdo cuvier & 98.39 & Galeocerdo cuvier MH911011.1 & 442 & 98 & Galeocerdo cuvier KX858829.1 & 798 & 99 & Near Threatened \\
\hline SF2 & Shark's fin & Sphyrna lewini & 99.19 & Sphyrna lewini MH911303.1 & 453 & 99 & Sphyrna lewini JX827259.1 & 684 & 94 & Endangered \\
\hline PS4 & Processed shark meat & Carcharhinus falciformis & 98.39 & Carcharhinus falciformis MH911159.1 & 446 & 99 & Carcharhinus falciformis KF801102.1 & 808 & 99 & Vulnerable \\
\hline PS5 & Processed shark meat & Carcharhinus falciformis & 98.39 & Carcharhinus falciformisMH911159.1 & 446 & 99 & Carcharhinus falciformis KF801102.1 & 815 & 99 & Vulnerable \\
\hline SS3 & Shark's skin & Carcharhinus leucas & 97.19 & Carcharhinus leucas MH230955.1 & 429 & 98 & $\mathrm{n} / \mathrm{a}$ & $\mathrm{n} / \mathrm{a}$ & $\mathrm{n} / \mathrm{a}$ & Near Threatened \\
\hline SS4 & Shark's skin & Carcharhinus leucas & 97.94 & Carcharhinus leucas MH230955.1 & 440 & 98 & $\mathrm{n} / \mathrm{a}$ & $\mathrm{n} / \mathrm{a}$ & $\mathrm{n} / \mathrm{a}$ & Near Threatened \\
\hline SS5 & Shark's skin & Carcharhinus falciformis & 97.93 & Carcharhinus falciformis MH911159.1 & 427 & 98 & $\mathrm{n} / \mathrm{a}$ & $\mathrm{n} / \mathrm{a}$ & $\mathrm{n} / \mathrm{a}$ & Vulnerable \\
\hline SS6 & Shark's skin & Carcharhinus falciformis & 98.39 & Carcharhinus falciformis MH911159.1 & 446 & 99 & $\mathrm{n} / \mathrm{a}$ & $\mathrm{n} / \mathrm{a}$ & $\mathrm{n} / \mathrm{a}$ & Vulnerable \\
\hline PS6 & Processed shark meat & Carcharhinus brevipinna & 98.81 & Carcharhinus brevipinna MH119961.1 & 448 & 99 & $\mathrm{n} / \mathrm{a}$ & $\mathrm{n} / \mathrm{a}$ & $\mathrm{n} / \mathrm{a}$ & Near Threatened \\
\hline PS7 & Curry cooked shark's meat & Galeocerdo cuvier & 97.99 & Galeocerdo cuvier MH911011.1 & 436 & 98 & $\mathrm{n} / \mathrm{a}$ & $\mathrm{n} / \mathrm{a}$ & $\mathrm{n} / \mathrm{a}$ & Near Threatened \\
\hline PS8 & Curry cooked shark's meat & Galeocerdo cuvier & 98.39 & Galeocerdo cuvier MH911011.1 & 442 & 98 & $\mathrm{n} / \mathrm{a}$ & $\mathrm{n} / \mathrm{a}$ & $\mathrm{n} / \mathrm{a}$ & Near Threatened \\
\hline
\end{tabular}


As can be seen in the result of molecular analysis (Table 1), the limitation of full-length DNA barcode (655 bp) could be replaced by a short universal primer pair targeting $226 \mathrm{bp}$ of COI marker. The $464 \mathrm{bp}$ of Cyt b marker was applied to validate the performance of miniDNA barcode. The overall finding was the performance of DNA mini barcode to be very similar to cyt $b$ results (Table 1). The comparison of COI mini marcode can be applied to all processed shark's food products. However, in the cyt b dataset, some of shark's food products ( 7 out of 21 samples) could not proceed into sequencing process or no results of species assignation. This problem was due to the type of food samples that might be contained complicated food matrix (Table 1). Most of samples were unambiguously identified as Carcharhinus falciformis, with the rest of samples identified as Carcharhinus sorrah, Alopias pelagicus, Rhynchobatus australiae, Galeocerdo cuvier, Sphyrna lewini, Carcharhinus leucas, Carcharhinus brevipinna (Table 1).

\section{Implication of molecular analysis in shark and rays sustainability}

Based on this study result, DNA mini-barcodes were successfully applied to heavily processed shark products. Though for some closely related species, low sequence variation in short mini barcode fragment might cause ambiguity and failed to provide further identification into species level (Mitchell and Hellberg 2016; Labrador et al. 2019). Researches on fish and seafood authentication have been established in many countries i.e. from Germany, Spain, Italy, Greece, USA, China, Taiwan, and Southeast Asian countries; however, there are fewer reports from Indonesia (Sembiring et al. 2015; Abdullah et al 2019). The correct assignation of fish on food labels is crucial to support the consumer demand for food safety and quality as well as the integrated traceability system. Mislabeling of fisheries and seafood products could affect the consumer health, considering that some traded globally fish may contain toxins as well as indigestible wax esters (from the escolar fish) or pollutant contamination (Chen et al. 2012; Pardo et al. 2016; Abdullah and Rehbein 2017). The increasing demand for new application methods such as targeted real-time PCR or isothermal amplification (e.g. loop-mediated isothermal amplification method (LAMP) to authenticate highly processed products will contribute to seafood control mechanism.

The intentional or unintentional fraud in the fish markets with endangered fish species is seen in the case of local catch of the hammerhead shark fin sample (Sample SF2, Table 1). SF2 sample was identified by BLAST as the scalloped hammerhead (Sphyrna lewini), which suffers from overexploitation. The particular attention of this study is sharks species identification toward more accountable Indonesian seafood labels traceability and marine sustainability. Most of seafood products sold in Indonesian commercial markets did not display label information regarding species authentication such as scientific name and origin of species. The results demonstrated most of samples in this study (13 out of 21 samples) were positively identified as threatened species that sold in the market (Table 1). Unfortunately, the result of this study demonstrated the endangered species of sharks are still traded locally or suspected internationally regardless of the species that has been regulated for international trade by Appendix II of CITES.

The fishery product commonly sold with various local names even when it is the same species of fish. However, specific regulations and guidelines to assist species identification of processed sharks and rays fishery are still not available in Indonesia. In accordance with this study, there is an urgent need to authenticate and identify the correct species name of Indonesian sharks and rays products. Previous researches of cytochrome oxidase I fulllength and mini DNA barcode markers demonstrated successful application and become standard analytical tools in some countries. Thus, it is urgently required to enforce standard DNA-based protocols for shark identification in the fish landing sites or commercial fish markets. Despite some efforts to manage sustainability in fishery sectors, it still suffers from legislative, law enforcement and managerial shortcomings. It is also important to provide an official national reference list of fish and seafood traded locally and internationally in order to help manage the fishery traceability and sustainability.

In summary, mini-DNA barcode and the cyt b gene fragments deliver an acceptable species discrimination markers of all processed sharks samples used in this study. DNA mini-barcoding may act as an alternative to authenticate seafood products that faced changes in the quality and quantity of DNA. The results of this study also highlighted there were no ambiguous species identification results, hence it is important to add new reference sequences to public databases (NCBI or FISH-BOL). It is expected that Indonesian fishery control authorities may provide national reference list of commercial fish and seafood that include their DNA sequences, in order to improve the quality and traceability of certain fishery products before it is exported to international markets.

\section{ACKNOWLEDGEMENTS}

We thank Muhammad Ichsan (WCS Indonesia) and Benaya Meitasari Simeone (WCS Indonesia) for collecting the sharks and rays samples. The first author is thankful to Ute Schröder and Prof. Dr. Jan Fritsche from the Department of Safety and Quality of Milk and Fish Products, Max Rubner-Institut, Germany for supporting some laboratory materials in this study. Dr. Asadatun Abdullah was gratefully acknowledging the support from the Indonesian Ministry of Research, Technology and Higher Education (RISTEKDIKTI) during postdoctoral grant (contract number: 174.2/D2.3/KP/2018).

\section{REFERENCES}

Abdullah A, Nurilmala M, Sitaresmi KP. 2019. DNA Mini-barcodes sebagai penanda molekuler untuk ketertelusuran label pangan berbagai produk ikan layur. Jurnal Pengolahan Hasil Perikanan Indonesia 22 (1): 33-40. [Indonesian] 
Abdullah A, Rehbein H. 2017. DNA barcoding for the species identification of commercially important fishery products in Indonesian markets. Intl J Food Sci Technol 52 (1): 266-274.

Almeron-Souza F, Sperb C, Castilho CL, Figueiredo PICC, Gonçalves LT, Machado R, Oliviera LR, Valiati VH, Fagundes NJ. 2018. Molecular identification of shark meat from local markets in Southern Brazil based on DNA barcoding: evidence for mislabeling and trade of endangered species. Front Genet 9: 138. DOI: 10.3389/fgene.2018.00138

Armani A, Guardone L, Castigliego L, D’Amico P, Messina A, Malandra R, Gianfaldoni D, Guidi A. 2015. DNA and Mini-DNA Barcoding for the identification of Porgies species (family Sparidae) of commercial interest on the international market. Food Contr 50: 589-596.

Barbuto M, Galimberti A, Ferri E, Labra M, Malandra R, Galli P, Casiraghi M. 2010. DNA barcoding reveals fraudulent substitutions in shark seafood products: The Italian Case of "palombo" (Mustelus spp.). Food Res Intl 43 (1): 376-381.

Bornatowski H, Braga RR, Vitule JRS. 2014. Threats to Sharks in A Developing Country: The Need For Effective Simple Conservation Measures. Natureza \& Conservacao 12 (1): 11-18

Carvalho DC, Palhares RM, Drummond MG, Frigo TB. 2015. DNA Barcoding identification of commercialized seafood in South Brazil: A governmental regulatory forensic program. Food Contr 50: 784-788.

Chen $\mathrm{CH}$, Hsieh $\mathrm{CH}$, Hwang DF. 2012. Species identification of Cyprinidae fish in Taiwan by FINS and PCR-RFLP analysis. Food Contr 28 (2): 240-245.

Dent F, Clarke S. 2015. State of The Global Market For Shark Products. FAO Fisheries and Aquaculture Technical Paper 590. FAO, Rome.

Di Pinto A, Marchetti P, Mottola A, Bozzo G, Bonerba E, Ceci E, Bottaro M, Tantillo G. 2015. Species identification in fish fillet products using DNA barcoding. Fish Res 170: 9-13.

Dulvy NK, Fowler SL, Musick JA, Cavanagh RD, Kyne PM, Harrison LR, Carlson JK, Davidson LNK, Fordham SV, Francis MP, Pollock CM, Simpfendorfer CA, Burgess GH, Carpenter KE, Compagno LJV, Ebert DA, Gibson C, Heupel MR, Livingstone SR, Sanciangco JC, Stevens JD, Valenti S, White WT. 2014. Extinction risk and conservation of the world's sharks and rays. Elife 3: e00590. DOI: 10.7554/eLife.00590

Dulvy NK, Simpfendorfer CA, Davidson LN, Fordham SV, Bräutigam A, Sant G, Welch DJ. 2017. Challenges and priorities in shark and ray conservation. Curr Biol 27 (11): R565-R572.

FAO [Food and Agriculture Organization of United Nations ]. 2015. State of the Global Market for Shark Products. FAO, Rome.

Giovos I, Arculeo M, Doumpas N, Katsada D, Maximiadi M, Mitsou E, Paravas V, Naasan Aga-Spyridopoulou R, Stoilas V-O, Tiralongo F, Tsamadias IE, Vecchioni L, Moutopoulos DK. 2020. Assessing multiple sources of data to detect illegal fishing, trade and mislabelling of elasmobranchs in Greek markets. Mar Pol 112 103730 .

Gryson N. 2010. Effect of Food Processing on Plant DNA Degradation and PCR-Based GMO Analysis: A Review. Anal Bioanal Chem 396 (6): 2003-2022.

Guenther B, Raupach MJ, Knebelsberger T. 2017. Full-length and minilength DNA barcoding for the identification of seafood commercially traded in Germany. Food Contr 73: 922-929.

Hajibabaei M, Janzen DH, Burns JM, Hallwachs W, Hebert PD. 2006. DNA barcodes distinguish species of tropical Lepidoptera. Proc Nat Acad Sci USA 103 (4): 968-971.

Hebert PD, Cywinska A, Ball SL, DeWaard JR. 2003. Biological identifications through DNA barcodes. Proc R Soc London Ser B Biol Sci 270 (1512): 313-321.

Horreo JL, Ardura A, Pola IG, Martinez JL, Garcia-Vazquez E. 2013. Universal primers for species authentication of animal foodstuff in a single polymerase chain reaction. J Sci Food Agri 93 (2): 354-361.

Horreo JL, Fitze PS, Jiménez-Valverde A, Noriega JA, Pelaez ML. 2019. Amplification of $16 \mathrm{~S}$ rDNA reveals important fish mislabeling in Madrid restaurants. Food Contr 96: 146-150.

Huang YR, Yin MC, Hsieh YL, Yeh YH, Yang YC, Chung YL, Hsieh CHE. 2014. Authentication of consumer fraud in Taiwanese fish products by molecular trace evidence and forensically informative nucleotide sequencing. Food Res Intl 55: 294-302

Jacquet JL, Pauly D. 2008. Trade secrets: Renaming and mislabeling of seafood. Mar Pol 32 (3): 309-318.
Kappel K, Schröder U. 2016. Substitution of high-priced fish with lowpriced species: adulteration of common sole in German restaurants. Food Contr 59: 478-486.

Kim MR, Kwon K, Jung YK, Kang TS. 2018. A rapid real-time PCR method to differentiate between Mottled Skate (Beringraja pulchra) and Other Skate and Ray Species. Food Chem 255: 112-119.

Labrador K, Agmata A, Palermo JD, Follante J, Pante MJ. 2019. Authentication of processed Philippine sardine products using hotshot DNA extraction and mini barcode amplification. Food Contr 98: 150-155.

Lindahl T. 1993. Instability and decay of the primary structure of DNA. Nature 362: 709-715. DOI: 10.1038/362709a0.

Messing J. 1983. [2] New M13 vectors for cloning. In Methods in Enzymology. Academic Press 101: 20-78.

Mitchell JK, Hellberg RS. 2016. Use of the mitochondrial control region as a potential DNA mini-barcoding target for the identification of canned tuna species. Food Anal Meth 9 (10): 2711-2720.

Muttaqin E, Abdullah A, Nurilmala M, Ichsan M, Simeone BM, Yulianto I, Booth H. 2019. DNA-barcoding as molecular marker for seafood forensics: species identification of locally consumed shark fish products in the world's largest shark fishery. IOP Conf Ser: Earth Environ Sci 278: 012049. DOI: 10.1088/1755-1315/278/1/012049.

Nagalakshmi K, Annam PK, Venkateshwarlu G, Pathakota GB, Lakra WS. 2016. Mislabeling in Indian seafood: an investigation using DNA barcoding. Food Contr 59: 196-200.

Pardo MA, Jiménez E, Perez-Villarreal B. 2016. Misdescription incidents in seafood sector. Food Contr 62: 277-283.

Pazartzi T, Siaperopoulou S, Gubili C, Maradidou S, Loukovitis D, Chatzispyrou A, Griffiths AM, Minos G, Imsiridou, A. 2019. High levels of mislabeling in shark meat-investigating patterns of species utilization with DNA barcoding in Greek Retailers. Food Contr 98: 179-186.

Pollack SJ, Kawalek MD, Williams-Hill DM, Hellberg RS. 2018. Evaluation of DNA barcoding methodologies for the identification of fish species in cooked products. Food Contr 84: 297-304

Sembiring A, Pertiwi NPD, Mahardini A, Wulandari R, Kurniasih EM, Kuncoro AW, Cahyani NKD, Anggoro AW, Ulfa M, Madduppa H, Carpenter KE, Barber PH, Mahardika GN. 2015. DNA barcoding reveals targeted fisheries for endangered sharks in Indonesia. Fish Res 164: 130-134.

Shokralla S, Hellberg RS, Handy SM, King I, Hajibabaei M. 2015. A DNA mini-barcoding system for authentication of processed fish products. Sci Rep 5: 15894. DOI: 10.1038/srep15894.

Staffen CF, Staffen MD, Becker ML, Löfgren SE, Muniz YCN, de Freitas RHA, Marrero AR. 2017. DNA barcoding reveals the mislabeling of fish in a popular tourist destination in Brazil. PeerJ 5: e4006. DOI: 10.7717/peerj.4006.

Steinke D, Bernard AM, Horn RL, Hilton P, Hanner R, Shivji MS. 2017. DNA analysis of traded shark fins and mobulid gill plates reveals a high proportion of species of conservation concern. Sci Rep 7 (1): 9505. DOI: 10.1038/s41598-017-10123-5

Stern DB, Nallar EC, Rathod J, Crandall KA. 2017. DNA barcoding analysis of seafood accuracy in Washington, DC restaurants. PeerJ. 5: e3234. DOI: $10.7717 /$ peerj.3234.

Sultana S, Ali ME, Hossain MM, Naquiah N, Zaidul ISM. 2018. Universal mini COI barcode for the identification of fish species in processed products. Food Res Intl 105: 19-28.

Tamura K, Stecher G, Peterson D, Filipski A, Kumar S. 2013. MEGA6: molecular evolutionary genetics analysis version 6.0. Mol Biol Evol 30 (12): 2725-2729.

Wolf C, Burgener M, Hübner P, Lüthy J. 2000. PCR-RFLP analysis of mitochondrial DNA: Differentiation of fish species. LWT-Food Sci Technol 33 (2): 144-150.

Xiong X, Yao L, Ying X, Lu L, Guardone L, Armani A, Guidi A, Xiong X. 2018. Multiple fish species identified from China's roasted Xue Yu fillet products using DNA and mini-DNA barcoding: Implications on human health and marine sustainability. Food Contr 88: 123-130.

Yulianto I, Booth H, Ningtias P, Kartawijaya T, Santos J, Sarmintohadi, Kleinertz S, Campbell SJ, Palm HW, Hammer C. 2018. Practical measures for sustainable shark fisheries: lessons learned from an Indonesian targeted shark fishery. PloS One 13 (11): e0206437. DOI: 10.1371/journal.pone.0206437.

Zhao W, Zhao Y, Pan Y, Wang X, Wang Z, Xie J. 2013. Authentication and traceability of Nibea albiflora from surimi products by speciesspecific polymerase chain reaction. Food Contr 31 (1): 97-101. 